\title{
EVALUATION OF AETIOLOGICAL ROLE OF MISDIRECTED TOOTH IN THE INCIDENCE OF SQUAMOUS CELL CARCINOMA OF ORAL CAVITY
}

\author{
Jagdish Prasad Purohit ${ }^{1}$, Sushil Kumar Kashyap², Manish Pandey33, Siva S4, Chandrabhann, Vineet Kumar ${ }^{6}$ \\ 1 Professor and HOD, Department of ENT, Head and Neck Surgery, MLB Medical College, Jhansi. \\ ${ }^{2}$ Associate Professor, Department of ENT, Head and Neck Surgery, MLB Medical College, Jhansi. \\ 3Junior Resident, Department of ENT, Head and Neck Surgery, MLB Medical College, Jhansi. \\ 4Junior Resident, Department of ENT, Head and Neck Surgery, MLB Medical College, Jhansi. \\ 5Junior Resident, Department of ENT, Head and Neck Surgery, MLB Medical College, Jhansi. \\ 'Junior Resident, Department of ENT, Head and Neck Surgery, MLB Medical College, Jhansi.
}

ABSTRACT
BACKGROUND
The incidence and progression of the oral cancer varies according to various cultural and lifestyle factors. In India, tobacco usage
in the form of smoked and non-smoked tobacco both is a common practice. In Western population smoking and alcohol consumption
are the main risk factors. Studies have shown that there is also role of non-modifiable risks like HPV infections and chronic irritation
by continuous trauma from misdirected tooth in causation of Oral Squamous Cell Carcinoma (OSCC).

AIMS

To find out the role played by chronic irritation due to misdirected tooth as an aetiological factor for OSCC.

\section{METHODS AND MATERIALS}

This is a retrospective clinical study done in 42 patients with OSCC from July 2014 to March 2016.

\section{RESULTS}

23.8\% patients who consumed alcohol and had misdirected tooth developed cancer, whereas only $4.76 \%$ patients with alcohol consumption history alone developed cancer; $26.19 \%$ patients used tobacco and had misdirected tooth developed cancer and only 7.14\% with tobacco usage alone developed cancer. In 19.04\% patients who took alcohol and tobacco both and with misdirected tooth developed cancers and in 7.14\% cases developed cancer when there is only history of alcohol and tobacco usage alone and no misdirected tooth was present; $7.14 \%$ patients developed cancers only with the presence of misdirected tooth alone; $4.76 \%$ patients developed cancer de novo even with not any risk factor involved.

\section{CONCLUSION}

We came to the conclusion that there is a significant role of irritation by misdirected tooth in the causation of OSCC as well as it is a major synergistic factor when combined with tobacco and alcohol consumption.

\section{KEYWORDS}

Misdirected Tooth, Chronic Mucosal Irritation, Oral Squamous Cell Carcinoma, Tobacco Use, Aetiological Factors.

HOW TO CITE THIS ARTICLE: Purohit JP, Kashyap SK, Pandey M, et al. Evaluation of aetiological role of misdirected tooth in the incidence of squamous cell carcinoma of oral cavity. J. Evolution Med. Dent. Sci. 2016;5(51):3260-3264, DOI: $10.14260 /$ jemds/2016/757

\section{INTRODUCTION}

Oral cavity consists of lips, buccal mucosa, alveolus and dentition, hard palate and anterior $2 / 3^{\text {rd }}$ of the tongue. Oral cavity carcinoma is the $6^{\text {th }}$ commonest cancer worldwide.[1] and the third most common in South East Asia.[2] Countries in Indian subcontinent especially India, Pakistan, Sri Lanka and Bangladesh have the highest incidence of oral carcinoma with up to $25 \%$ of all new cases.[3] compared to $6 \%$ in France and $3 \%$ in the UK. ${ }^{[4]}$ In India head and neck squamous cell carcinoma is one of the most common cancers. In India, Bhopal has the highest age adjusted incidence rates of 9.6 of 100,000

Financial or Other, Competing Interest: None.

Submission 29-04-2016, Peer Review 04-06-2016,

Acceptance 10-06-2016, Published 25-06-2016.

Corresponding Author:

Dr. Manish Pandey,

Room No. 4; 80 PG Married Hostel,

MLB Medical College,

Jhansi-284128,

Uttar Pradesh, India.

E-mail: dr.manishp004@gmail.com

DOI: $10.14260 /$ jemds $/ 2016 / 757$ males for oral cancer.[2] Histologically, the most common type of oral carcinoma is squamous cell carcinoma which accounts for $90 \%$ of the oral carcinomas followed by adenocarcinoma $5 \%$, lymphomas $2 \%$, verrucous carcinoma $2 \%$ and the rest are relatively rare like sarcomas.[5] The commonest site of involvement of the oral carcinoma is tongue (up to 50\%) where lateral borders and anterior $2 / 3^{\text {rd }}$ are being commonly involved.[6]

Oral Squamous Cell Carcinoma (OSCC) is a malignant tumour of the squamous lining of the oral cavity mucosa. The incidence of OSCC is high at around sixth and seventh decade of life and the risk is more in men compared to women. $[7,8]$ According to a few recent studies, although the global incidence of OSCC has decreased, the incidence has increased among people less than 40 years of age.[6] One more study done by Warnakulasuriya S, et al; 2007 also reported increasing incidence of OSCC in patients under 45 years of age. ${ }^{[9]}$

The incidence and progression of the oral cancer varies significantly according to the various cultural and lifestyle factors. Hence, incidence of oral cancer varies in different parts 
of the world. The cultural habit of Alcohol use in parts of Western Europe has been associated with high incidence of OSCC.[10] In Bundelkhand region of India, where our study was conducted and also in other parts of Indian sub-continent tobacco chewing, betel nut chewing, gutkha chewing is a common practice. Gutkha is a local preparation of areca nut and tobacco. Betel Nut has Arecoline a brother of Acetylcholine which acts on neuromuscular junction causing constant muscle spasm. While irritable and ulcerative component in it damages the mucosa and submucosa which heal on these muscle already in spasm, leading to contracture and more contracture. This fibrosed mucosa is not pliable during chewing, so even slightly misdirected tooth starts rubbing and damaging it leading to carcinoma of buccal mucosa or tongue at that site quite often. Scale made of tobacco quid deposited on teeth and gum junction causes Periodontitis and Carcinoma of lower gingivobuccal sulcus. While on upper gingivobuccal sulcus, same can occur but is less common.

Recent studies have shown that there is a role of carcinogenic viruses like Human Papilloma virus and chronic irritation caused by continuous trauma from misdirected tooth or jagged tooth in causation of squamous cell carcinoma of the oral cavity. Misdirected tooth especially the sharp border of the lower first molar tooth tends to cause chronic irritation to the lateral aspect of the tongue if it is directed lingually and to the buccal mucosa if it is directed buccally causing CA tongue and CA cheek respectively.

If a patient having misdirected tooth also consumes alcohol or tobacco, it can cause more tissue damage increasing the incidence of cancer.[11] Dental trauma caused by edges of a sharp, jagged and misdirected tooth is an important aetiology of OSCC.[12] Nitrosonornicotine, Aryl Hydrocarbons (Most common of it is Benzopyrene that is known as common tar of tobacco) are the carcinogenic substance present in the tobacco that increases the risk of cancers by causing tissue damage at molecular level.

There is also a group of OSSC patients without any history of tobacco and alcohol consumption. ${ }^{[13,14]}$ For these patients, the aetiologic factors including HPV 16-18, diet and nutrition especially deficient in vit A, C, D; Iron and Zinc, genetics, oral hygiene, dental trauma might play a significant role and many studies have been done and still so many researches are going on. $[14,15,16,17,18]$

The parts of oral cavity like lips, tongue and buccal mucosa are easily visible and cancers of these parts usually present at a relatively early stage. Retromolar Trigone (RMT) is an illdefined triangular area in the oral cavity posterior to the upper and lower third molar teeth with the maxillary tuberosity at its apex. It is a relatively uncommon site for oral squamous cell carcinoma. Jagged tooth mainly upper last molar is a common cause of CA retromolar trigone. The prognosis for retromolar trigone area SCC is poor because of the presentation at an advanced stage.[19,20,21]

This study has been conducted with an aim to evaluate the aetiological role of presence of misdirected tooth in oral squamous cell carcinoma.

\section{METHODS AND MATERIALS}

This is a retrospective study conducted in the Department of ENT and Head and Neck surgery, MLB Medical College, Jhansi, Uttar Pradesh, India. The study included 48 patients who came to the OPD with non-healing chronic ulcer (s) in the oral cavity between the interval of July 2014 and March 2016.

\section{Inclusion Criteria}

Patients who came to our OPD with history of chronic nonhealing oral ulcers were taken and examined in this study.

\section{Exclusion Criteria}

Patients having other of oral lesions like oral lichen planus, oral candidiasis, aphthous ulcers, any lacerations or any other acute lesions were not included in this study. Patients having any other dermatological illnesses or any other systemic illnesses were also not included in the study.

Complete history taking and local examination of the lesion was done in the OPD. All the patients had chronic nonhealing ulcer or swelling in the oral cavity were admitted as inpatients and punch biopsy was done under local anaesthesia. Histopathological evaluation of the sample was done by experts and the results turned out to be squamous cell carcinoma in case of 42 patients $(87.5 \%)$ and the rest 6 cases were non-neoplastic lesions (Exclusion criteria) of nonspecific causes (Table 1 and Figure 1).

Our study was concentrated to only these 42 patients and the underlying risk factors for every individual patient were identified by further probing into the history in detail. Special attention was given to the relationship between the chronic irritation caused to the oral mucosa by misdirected or jagged tooth and the incidence of squamous cell carcinoma of the oral cavity.

Dental trauma was classified into three basic conditions namely dental decay, broken teeth and teeth with sharp margins. We also considered tobacco smoking habits of the patients like number of cigarettes per day. Additionally, former smokers and former drinkers were defined as individuals who had stopped smoking and drinking for at least 2 years at the time of the interview. According to UK Department of Health, alcohol consumption for men who drink less than 21 units/week and for women who drink less than 14 units/week is not classified as abusive.[11]

\section{RESULTS}

Out of the 42 OSCC cases, 38 were males and 4 were females (Table 2). The patients were belonging to different age groups ranging from 20 years to 80 years with the maximum number of patients coming under the $41-60$ years of age $(47.61 \%)$ (Table 3).

22 patients (52.38\%) were having squamous cell carcinoma originating from tongue followed by 18 cases of buccal mucosa. Lesions of cancer in other sites of oral cavity were 2 cases, who were having ulcer in retromolar trigone. In our study we did not encounter a single patient with exclusively alveolar involvement (Table 4).

$10(23.8 \%)$ patients who consumed alcohol along with the presence of misdirected tooth developed cancer, whereas only $2(4.76 \%)$ patients with alcohol consumption history alone developed cancer; 11 (26.19\%) patients who had history of tobacco usage along with the presence of misdirected tooth developed cancer and only $3(7.14 \%)$ patients with tobacco usage alone developed cancer of the oral cavity. In 8 (19.04\%) patients with history of alcohol and tobacco usage along with misdirected tooth developed cancers and in 3 (7.14\%) cases they developed cancer where there is only history of alcohol and tobacco usage alone and no misdirected tooth was present; 3 (7.14\%) patients developed cancers only with the 
presence of misdirected tooth alone; 2 (4.76\%) patients developed cancer de novo even with not any risk factor involved (Table 5 and Figure 2).

\begin{tabular}{|c|c|}
\hline Diagnosis & Number of Cases \\
\hline Malignant ulcer or growth & 42 \\
\hline Non-malignant ulcer or growth & 6 \\
\hline \multicolumn{2}{|c|}{ Table 1: Showing the Various Diagnosis } \\
among the Cases Studied (n=48)
\end{tabular}

\begin{tabular}{|c|c|c|}
\hline Sex & Male & Female \\
\hline Number & 38 & 4 \\
\hline Percentage & $90.47 \%$ & $9.53 \%$ \\
\hline Table 2: Showing the Sex Distribution among the Cases \\
Diagnosed to have Oral Squamous Cell Carcinoma \\
\hline
\end{tabular}

\begin{tabular}{|c|c|c|c|c|}
\hline $\begin{array}{c}\text { Age } \\
\text { Group }\end{array}$ & $\begin{array}{c}<\mathbf{2 0} \\
\text { years }\end{array}$ & $\begin{array}{c}\mathbf{2 0 - 4 0} \\
\text { years }\end{array}$ & $\begin{array}{c}\mathbf{4 1 - 6 0} \\
\text { years }\end{array}$ & $\begin{array}{c}>61 \\
\text { years }\end{array}$ \\
\hline $\begin{array}{c}\text { No. of } \\
\text { cases }\end{array}$ & - & 4 & 20 & 18 \\
\hline Percentage & $0 \%$ & $9.53 \%$ & $47.61 \%$ & $42.86 \%$ \\
\hline \multicolumn{5}{|c|}{ Table 3: Shows the Age Group of the } \\
Patients having Malignancy \\
\hline
\end{tabular}

\begin{tabular}{|c|c|c|c|c|}
\hline $\begin{array}{c}\text { Site of } \\
\text { Lesion }\end{array}$ & Tongue & $\begin{array}{c}\text { Cheek } \\
\text { Mucosa }\end{array}$ & Alveolus & $\begin{array}{c}\text { Retro } \\
\text { Molar } \\
\text { Trigone }\end{array}$ \\
\hline $\begin{array}{c}\text { No. of } \\
\text { cases }\end{array}$ & 22 & 18 & - & 2 \\
\hline Percentage & $52.38 \%$ & $42.86 \%$ & $0 \%$ & $4.76 \%$ \\
\hline Table 4: Showing the Various Sites of Involvement of the \\
Squamous Cell Carcinoma in the Oral Cavity \\
\hline
\end{tabular}

\begin{tabular}{|c|c|c|c|}
\hline $\begin{array}{l}\text { Risk Factors for } \\
\text { OSCC }\end{array}$ & \multicolumn{2}{|c|}{$\begin{array}{l}\text { No. of Patients with } \\
\text { the Mentioned Risk }\end{array}$} & Percentage \\
\hline \multirow{2}{*}{$\begin{array}{c}\text { Alcohol } \\
\text { consumption } \\
\text { alone }\end{array}$} & $\begin{array}{l}\text { With presence of } \\
\text { misdirected } \\
\text { tooth }(\mathrm{AmD})\end{array}$ & 10 & $23.8 \%$ \\
\hline & $\begin{array}{c}\text { Without } \\
\text { presence of } \\
\text { misdirected } \\
\text { tooth }(\mathrm{AWmD})\end{array}$ & 2 & $4.76 \%$ \\
\hline \multirow{2}{*}{$\begin{array}{l}\text { Tobacco usage } \\
\text { alone (smoking or } \\
\text { smokeless } \\
\text { tobacco) }\end{array}$} & $\begin{array}{l}\text { With presence of } \\
\text { misdirected } \\
\text { tooth (TmD) }\end{array}$ & 11 & $26.19 \%$ \\
\hline & $\begin{array}{c}\text { Without } \\
\text { presence of } \\
\text { misdirected } \\
\text { tooth (TWmD) }\end{array}$ & 3 & $7.14 \%$ \\
\hline \multirow{2}{*}{$\begin{array}{l}\text { Both alcohol and } \\
\text { tobacco } \\
\text { consumption }\end{array}$} & $\begin{array}{l}\text { With presence of } \\
\text { misdirected } \\
\text { tooth }(\mathrm{CmD})\end{array}$ & 8 & $19.04 \%$ \\
\hline & $\begin{array}{c}\text { Without } \\
\text { presence of } \\
\text { misdirected } \\
\text { tooth }(\mathrm{CWmD})\end{array}$ & 3 & $7.14 \%$ \\
\hline $\begin{array}{c}\text { Presence of } \\
\text { misdirected tooth } \\
\text { alone }\end{array}$ & \multicolumn{2}{|l|}{3} & $7.14 \%$ \\
\hline $\begin{array}{c}\text { Not having any of } \\
\text { the above } \\
\text { mentioned risk } \\
\text { factors }\end{array}$ & \multicolumn{2}{|l|}{2} & $4.76 \%$ \\
\hline
\end{tabular}

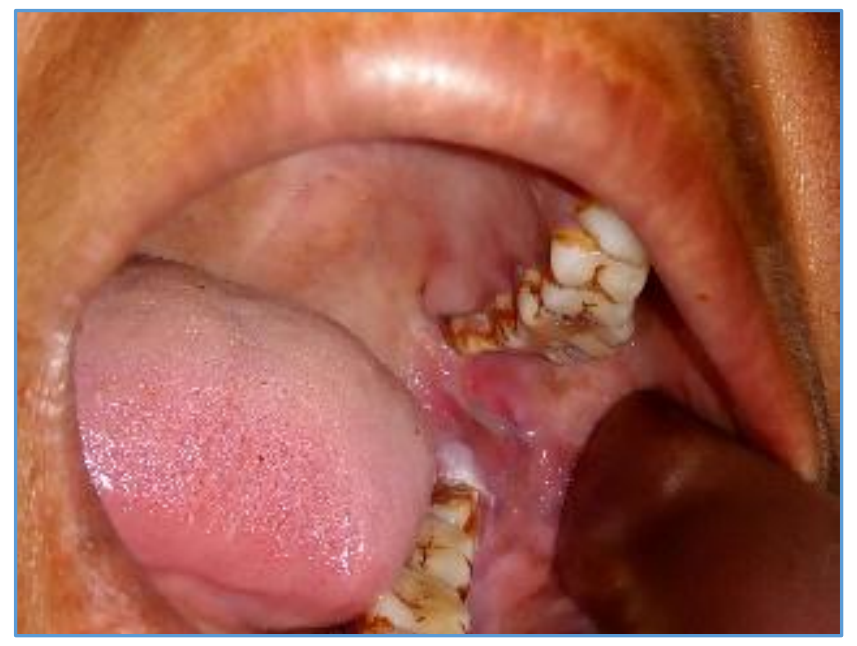

Fig. 1: Misdirected Upper Last Molar Tooth Buccally causing Ulcer over Left Buccal Mucosa

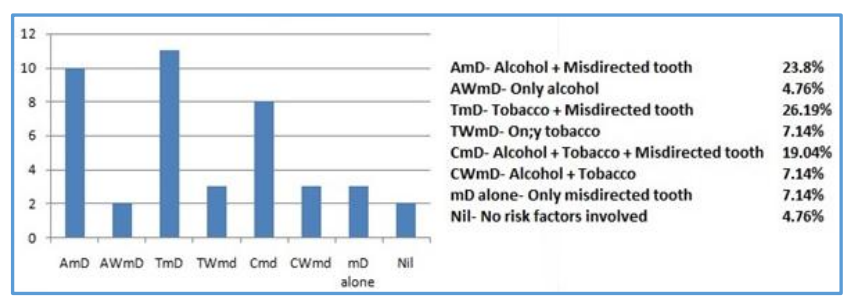

Fig. 2: Bar Diagram showing the Number of Cases with Various Aetiological Factors and Discussed

\section{DISCUSSION}

OSCC especially occurs in males.[12,16,22,23,24] whereas in our study we are having more number of male patients with carcinoma, i.e. $90.47 \%$ to only $9.53 \%$ in females. This can be attributed to the higher number of male patients with alcohol or tobacco abuse in India.

Among the different sites of OSCC, carcinoma tongue is the most common (Approximately 50\%).[2,25] Other studies like (Huang et al, 2006; Rao et al, 2013; Yazici et al, 2005) also supports the commonest incidence of carcinoma tongue. $[26,27,28]$ In our study, carcinoma tongue is present in $52.38 \%$ of the patients which is on par with the other studies. Total number of alcoholic patients having misdirected tooth are having increased risk of $19.03 \%$ than not having misdirected tooth. Total number of tobacco users having misdirected tooth are having increased risk of $19.04 \%$ than not having misdirected tooth. Total number of patients (Alcoholic and Tobacco users both) having misdirected tooth are having increased the risk by $11.89 \%$ than not having misdirected tooth.

Chronic physical irritation of oral mucosa by misdirected tooth may be an independent cause of OSCC. [29] In this study patients having only misdirected tooth without any other risk factors have $7.14 \%$ risk of developing oral cancer. While in our study, $4.76 \%$ patients who are not having misdirected tooth or any other behavioural risk factors developed oral cancer. It shows that oral cancers can occur even without having any of the above mentioned risk factors.

Misdirected tooth and tobacco usage cause constant irritation to the oral mucosa. It is a very common aetiology of oral SCC.[30] Lockhart PB et al reported that $44 \%$ of patients 
with OSCC of tongue origin had a site of constant irritation by sharp teeth or dentures. ${ }^{[31]}$

The incidence of oral SCC involving buccal mucosa is quite common in Asian populations, especially Indian sub-continent countries due to cultural betel quid and tobacco chewing habits. In Sri Lanka, OSCC involving buccal mucosa accounts for $40 \%$ of all OSCC cases. [2,32] Buccal mucosa comes out to be the second commonest site $(42.85 \%)$ of oral squamous cell carcinoma in our study in which right buccal mucosa proves to be more common. It can be attributed to the local practice of keeping tobacco and Gutkha in the right vestibule as told by the patients during history and examination session.

Patients were chewing tobacco and some patients were also giving history of keeping it inside the mouth while sleeping. This caused long duration of contact and irritation to the buccal mucosa.

Alcohol and Tobacco causes their carcinogenic effects by contact mechanism. Studies in animal models have shown that there is an effect of ethanol on the penetration of nitrosonornicotine (From tobacco) into the oral mucosa.[33]

\section{CONCLUSION}

This clinical retrospective study included 48 patients having chronic non-healing ulcer(s) in the oral cavity between the interval of July 2014 and March 2016. On histopathological examination, 42 patients were found to be OSCC patients.

These 42 patients were examined clinically for the presence of misdirected tooth and whether this misdirected tooth causing constant irritation or trauma to nearby structures in oral cavity leading to chronic non-healing ulcer. The data mentioned above strongly supports the hypothesis that chronic mechanical trauma caused by misdirected tooth plays a role in aetiology of oral SCC.

Males show a higher incidence of oral SCC compared to the females. Carcinoma tongue is the most common site of OSCC. Patients with oral SCC are most likely to be in the age group of 40-60 years. Our results are consistent with the results that chronic physical irritation or trauma caused by misdirected tooth is likely to cause OSCC and this can be considered as an independent risk factor.

\section{REFERENCES}

1. Ferlay J, Pisani P, Parkin DM. Globocan 2002, cancer incidence, mortality and prevalence worldwide IARC, cancer base (2002 estimates) Lyon. IARC press 2004.

2. Warnakulasuriya S. Global epidemiology of oral and oropharyngeal cancer. Oral Oncol 2009;45(4-5):309-16.

3. Curado MP, Edwards B, Shin HR, et al. IARC cancer incidence in five continents. Lyon IARC press 2007; Vol IX.

4. Brocklehurst P, Kujan O, Glenny AM, et al. Screening programme for the early detection and prevention of oral cancer. Cochrane Database of Systematic Review 2010;11:CD004150.

5. Agar NJM, Patel RS. Early detection, causes and screening of oral cancer. JSM Dent 2014;2(3):1039.

6. Albuquerque R, López-López J, Marí-Roig A, et al. Oral tongue squamous cell carcinoma (OTSCC): alcohol and tobacco consumption versus non-consumption. A study in a Portuguese population. Braz Dent J 2011;22(6):51721.
7. Garavello W, Spreafico R, Gaini RM. Oral tongue cancer in young patients: a matched analysis. Oral Oncol 2007;43(9):894-7.

8. Benevenuto TG, Nonaka CF, Pinto LP, et al. Immunohistochemical comparative analysis of cell proliferation and angiogenic index in squamous cell carcinomas of the tongue between young and older patients. Appl Immunohistochem Mol Morphol 2012;20(3):291-7.

9. Warnakulasuria S, Mak V, Mollar H. Oral cancer survival in young people in South East England. Oral Onco 2007;43(10):982-6.

10. Pontes FS, Carneiro JT, Fonseca FP, et al. Squamous cell carcinoma of the tongue and floor of the mouth: analysis of survival rate and independent prognostic factors in the Amazon region. J Craniofac Surg 2011;22(3):925-30.

11. Bektas-Kayhan K, Karagoz G, Kesimli MC, et al. Carcinoma of the tongue: a case-control study on aetiologic factors and dental trauma. Asian pac J cancer prev 2014;15(5):2225-9.

12. Neville BW, Day TA. Oral cancer and precancerous lesions. CA Cancer J Clin 2002;52:195-215.

13. Dahlstrom KR, Little JA, Zafereo ME, et al. Squamous cell carcinoma of the head and neck in never smoker-never drinkers a descriptive epidemiologic study. Head Neck 2008;30(1):75-84.

14. Wight R, Paleri V, Arullendran P. Current theories for the development of nonsmoking and nondrinking laryngeal carcinoma. Curr Opin Otolaryngol Head Neck Surg 2003;11(2):73-7.

15. Goldergberg D, Lee J, Koch WM, et al. Habitual risk factors for head and neck cancer. Otoloryngol Head and Neck Surg 2004;131(6):986-93.

16. Sturgis EM, Wei Q, Spitz MR. Descriptive epidemiologic and risk factors for head and neck cancer. Semin Oncol 2004;31(6):726-33.

17. Mehrotra R, Singh M, Kumar D, et al. Age specific incidence rate and pathological spectrum of oral cancer in Allahabad. Indian J Med Sci 2003;57(9):400-4.

18. Johnson N. Tobacco use and oral cancer: a global perspective. J Dent Educ 2001;65(4):328-39.

19. Byers R, Anderson B, Schwars E. Treatment of squamous cell carcinoma of the retromolar trigone. Am J Clin Oncol 1984;7:647-52.

20. Kowalski LP, Hashimoto I, Magrin J. End results of 114 extended "commando" operation for the retromolar trigone carcinoma. Am J Surg 1993;166(4):374-9.

21. Antoniadoes $\mathrm{K}$, Lazardidis N, Vahtsevanos $\mathrm{K}$, et al. Treatment of squamous cell carcinoma of the anterior faucial pillar-retromolar trigone. Oral Oncol 2003;39(7):680-6.

22. Schmidt BL, Dierks EJ, Homer L, et al. Tobacco smoking history and presentation of oral squamous cell carcinoma. J Oral Maxillofac Surg 2004;62(9):1055-8.

23. Vineis $P$, Alavanja $M$, Buffler $P$, et al. Tobacco and cancer: recent epidemiological evidence. J Natl Cancer Inst 2004;96(2):99-106.

24. Massano J, Regateiro FS, Januário G, et al. Oral squamous cell carcinoma: review of prognostic and predictive factors. Oral Surg Oral Med Oral Pathol Oral Radiol Endod 2006;102(1):67-76. 
25. Markopoulos AK. Current aspects on oral squamous cell carcinoma. Open Dent J 2012;6:126-30.

26. Huang X, Wei Y, Li L, et al. Serum proteomics study of the squamous cell carcinoma antigen 1 in tongue cancer. Oral Oncol 2006;42(1):26-31.

27. Rao KSV, Mejia G, Roberts-Thomson K, et al. Epidemiology of oral cancer in Asia in the past decade-an update (2000-2012). Asian Pac J Cancer Prev 2013;14(10):5565-77.

28. Yazici YD, Kim S, Jasser SA, et al. Antivascular therapy of oral tongue squamous cell carcinoma with PTK787. Laryngoscope 2005;115(12):2249-55.

29. Behnoud F, Torabian S, Zargaran M. Relationship between oral poor hygiene and broken teeth with oral tongue squamous cell carcinoma. Acta Med Iran 2011;49(3):159-62.
30. Kumar MR, Umashankar DN, Sharma R, et al. Carcinoma of anterior two third of the tongue: a case report. International Journal of Oral \& Maxillofacial Pathology 2011;2(3):55-8.

31. Lockhart PB, Norris CM, Pulliam C. Dental factors in the genesis of squamous cell carcinoma of the oral cavity. Oral Oncol 1998;34(2):133-9.

32. Laronde DM, Hislop TG, Elwood JM, et al. Oral cancer: just the facts. J Can Dent Assoc 2008;74(3):269-72.

33. Fan H, Yoon KY, Kim SM, et al. Relationship between SCC of tongue \& the position of dental prosthesis. J Adv Prosthodont 2015;7(2):129-37. 